\title{
The first five-year evaluation of cystic fibrosis neonatal screening program in São Paulo State, Brazil
}

\author{
Uma avaliação dos primeiros cinco anos do \\ programa de triagem neonatal da fibrose \\ cística no Estado de São Paulo, Brasil
}

\section{Una evaluación de los primeros cinco años del programa de cribado neonatal de fibrosis cística en el Estado de São Paulo, Brasil}

Léa Maria Zanini Maciel 1

Patrícia Künzle Ribeiro Magalhães 1 Ieda Regina Lopes Del Ciampo 1

Maria Luísa Barato de Sousa 1 Maria Inez Machado Fernandes 1

Regina Sawamura 1

Roberta Rodrigues Bittar 1

Greice Andreotti de Molfetta 1

Wilson Araújo da Silva Júnior 1

\begin{abstract}
The Hospital of the Ribeirão Preto Medical School, University of São Paulo is one of the three screening centers in São Paulo State, Brazil, and has included a test for cystic fibrosis (CF) since February 6, 2010, by a court order. We evaluated the first five years of this CF-newborn screening program. The original immunoreactive trypsinogen (IRT)/IRT screening protocol was adopted in Brazil. A total of 173,571 newborns were screened, 1,922 (1.1\%) of whom showed IRT1 $\geq 70 \mathrm{ng} / \mathrm{mL}$. Of these, 1,795 (93.4\%) collected IRT2, with elevated results (IRT $2 \geq 70 \mathrm{ng} / \mathrm{mL}$ ) in 102 of them (5.2\%). We identified a total of 26 CF cases during this period, including three CF cases that were not detected by the CF-newborn screening. The incidence of the disease among the screened babies was 1:6,675 newborns screened. Median age at the initial evaluation was 42 days, comparable to that of neonates screened with the IRT/DNA protocol. Almost all infants with CF already exhibited some manifestations of the disease during the neonatal period. The mutation most frequently detected in the CF cases was F508del. These findings suggest the early age at the beginning of treatment at our center was due to the effort of the persons involved in the program regarding an effective active search. Considering the false negative results of CF-newborn screening and the early onset of clinical manifestations of the disease in this study, pediatricians should be aware of the diagnosis of CF even in children with negative test.
\end{abstract}

Cystic Fibrosis; Neonatal Screening; Trypsinogen

\author{
Correspondence \\ L. M. Z. Maciel \\ Hospital das Clínicas, Faculdade de Medicina de Ribeirão Preto, \\ Universidade de São Paulo. \\ Av. Bandeirantes 3900, Ribeirão Preto, SP 14049-900, Brasil. \\ lmzmacie@fmrp.usp.br \\ 1 Faculdade de Medicina de Ribeirão Preto, Universidade de \\ São Paulo, Ribeirão Preto, Brasil.
}




\section{Introduction}

Cystic fibrosis (CF) is a hereditary autosomal recessive disease with an incidence ranging from 1:2,000 to 1:10,000 among Caucasians in several countries 1,2,3. In Brazil, its incidence has been estimated at 1:7,576 to $1: 8,400$ live births 4,5 . CF is associated with changes in the ion transport regulatory transmembrane protein (CFTR - cystic fibrosis transmbrane regulatory), which, among other functions, acts as a chloride channel that carries this ion out of the cell 6 . More than 2,000 mutations in the CFTR gene have already been described and, depending on the mutation, the protein defect may be more or less severe, with consequent differences in the clinical presentation of the disease or in the patient's age at the onset of the disease 7 .

Newborn screening for CF (CF-NBS) became available in 19798 and in recent years has been expanded around the world 9 .

Immunoreactive trypsinogen (IRT) determination is the starting point for NBS in all protocols used thus far 10 although IRT levels can be elevated in various situations not related to CF 11 . The original IRT/IRT screening protocol was adopted in Brazil in view of the ethnic heterogeneity of the Brazilian population and the need to investigate various mutations, despite the known large number of false-positive results 12,13 which induce unnecessary anxiety in the parents until the diagnosis of $\mathrm{CF}$ can be ruled out.

In Brazil, CF-NBS has been performed in some states (Paraná, Santa Catarina and Minas Gerais) since 2001, but in São Paulo State it began only on February 6, 2010. Currently, the entire country has introduced CF-NBS.

In São Paulo State, there are three neonatal screening centers: Hospital of the Ribeirão Preto Medical School, University of São Paulo (HCFMRP-USP), University of Campinas (UNICAMP) and Association of Parents and Friends of the Exceptional (APAE) of São Paulo. NBS Program of HCFMRP-USP covers the screening of children born in the northeastern region of São Paulo State.

The objectives of this study are to report the data regarding CF-NBS at HCFMRP-USP and to perform a critical analysis of the results of this screening five years after its implementation.

\section{Patients and methods}

We analyzed retrospectively the results of all newborns whose NBS tests were sent to HCFMRP-USP from February 6, 2010 to January 31, 2015, and the clinical and laboratory data of all babies whose screening was positive for the disease and who were therefore evaluated at the Cystic Fibrosis Outpatient Clinic of HCFMRP-USP. We also included babies with a negative CF-NBS, but with a CF diagnosis confirmed by clinical signs and symptoms suggestive of the disease and a positive sweat chloride test (SCT). For data collection, we used the database of the Neonatal Screening Laboratory of HCFMRP-USP, the records of the hospital system and clinical records of the children diagnosed with CF.

The strategy used for CF-NBS was the IRT/IRT protocol, which recommends a first collection of the test (IRT1) between the third and fifth day of life and a second IRT collection (IRT2) between three and four weeks of life for children with IRT1 results $\geq 70 \mathrm{ng} / \mathrm{mL}$. If the IRT2 value remained high $(\geq 70 \mathrm{ng} / \mathrm{mL})$, the children were re-called for clinical evaluation and the SCT was performed for diagnostic confirmation. Collections were considered to be late when IRT1 was collected at more than 15 days of age, a situation in which IRT1 was considered to be IRT2, or when IRT1 or IRT2 was collected after more than 30 or 45 days, respectively.

Blood samples were collected on Schleicher \& Schuell \# 903 filter paper (Lot W041; Germany) at the hospitals and basic health care units of the cities and sent to the Screening Laboratory of HCFMRP-USP. IRT was measured with the commercial DELFIA Neonatal IRT kit (time-resolved fluoroimmunoassay kit A005-110, Wallac Oy, USA) using immunofluorimetric methodology according to the manufacturer's guidelines. The intra-assay coefficient of variation was $5.9 \%$ at the concentration of $20.0 \mathrm{ng} / \mathrm{mL}$ and the inter-assay error was $6.7 \%$ at the concentration of $26.4 \mathrm{ng} / \mathrm{mL}$. The method used in the SCT is based on the stimulation of pilocarpine sweating and iontophoresis in the 
forearm 14 and subsequent determination of chloride in sweat-soaked gauze by spectrophotometry using the modified 15 commercial kit (Labtest Diagnostica S.A., Brazil).

Chloride concentrations in the sweat test below $30 \mathrm{mEq} / \mathrm{L}$ were considered normal and concentrations higher than $60 \mathrm{mEq} / \mathrm{L}$ were considered to represent a diagnosis of $\mathrm{CF}$. Intermediate values between 30 and $60 \mathrm{mEq} / \mathrm{L}$ were considered to be doubtful, and the test was repeated on another day.

The results of NBS tests were considered to be false positive in the presence of two results of IRT $\geq 70 \mathrm{ng} / \mathrm{mL}$ followed by a normal SCT and to be false negative when the child had one or two normal IRTs, and the diagnosis of CF was performed based on clinical manifestations of the disease and two positive SCT.

Clinical evaluation of babies with IRT1 and IRT $2 \geq 70 \mathrm{ng} / \mathrm{mL}$ was performed by a pediatric gastroenterology specialist after the SCT. All children diagnosed with CF and those with a SCT in the doubtful range were referred to the CF Outpatient Clinic for follow-up.

Clinical manifestations of the patients diagnosed with $\mathrm{CF}$ were collected at the first consultation in the specialized clinic and were subdivided as follows: gastrointestinal in the presence of steatorrhea, vomiting or diarrhea; respiratory in the presence of persistent coughing, wheezing or repetitive "pneumonia", and/or "metabolic" in the presence of dehydration or lack of weight gain.

The variables studied were: median age (interquartile range - IQR) of the child at collection of the first IRT, positivity in the NSB test and in the SCT, sensitivity and specificity of the NBS test, time of $\mathrm{CF}$ diagnosis and initial clinical manifestations of babies with a diagnosis of CF. Babies with meconium ileus were excluded from the determination of sensitivity 16 . The dates of each NBS step were analyzed in order to determine the effectiveness of the CF-NBS Program.

\section{DNA amplification and molecular analysis}

\section{- Sanger sequencing assay}

Eighteen patients (Table 1) were subjected to sequencing of the entire CFTR coding region. Genomic DNA was extracted from peripheral blood leukocytes using the Wizard Genomic DNA Purification kit (Promega, Madison, USA) according to the manufacturer's instructions. Thirty-two pairs of primers were designed to amplify the 27 exons and adjacent intronic regions of the CFTR gene (primer sequences and PCR conditions available upon request). The PCR-amplified DNA fragments were subjected to direct sequencing with an automatic capillary sequencing system (ABI 3500X Genetic Analyzer, Applied Biosystems, Foster City, USA) using the Big Dye terminator v3.1 cycle sequencing kit (Applied Biosystems) and the same PCR primers, following the manufacturer's instructions. Results were analyzed using the FinchTV software, version 1.4.0 (https://digitalworldbiology.com/ FinchTV) and the sequences obtained were compared to the reference of the GenBank database (NM_000492).

\section{- Multiplex Ligation-dependent Probe Amplification (MLPA) assay}

Patients bearing none or heterozygous for CFTR deleterious mutations were submitted to MLPA for the screening of deletions or duplications in CFTR gene. We employed the SALSA MLPA P091CFTR kit (MRC-Holland), according to manufacturer's instructions. Results were analyzed using the software Coffalyser for MLPA data interpretation.

\section{Results}

From February 2010 to January 2015, 176,562 births occurred according to the Brazilian Information System on Live Births (SINASC) and 173,571 newborn were subjected to the NBS test at HCFMRPUSP. The median age (IQR) at test collection (IRT1) was 5.0 (4-7) days. Of the total number of children screened, $1,946(1.1 \%)$ presented IRT1 $\geq 70 \mathrm{ng} / \mathrm{mL}$. Of these, 1,795 (93.4\%) collected IRT2, with a result $\geq 70 \mathrm{ng} / \mathrm{mL}$ in 102 of them (5.7\%) (Figure 1). The median [IQR] age for the collection of IRT2 was 28 (24-33) days. 
Table 1

Clinical and laboratory data of newborns with cystic fibrosis detected at Hospital of the Ribeirão Preto Medical School, University of São Paulo, from February 2010 to January 2015.

\begin{tabular}{|c|c|c|c|c|c|c|c|c|c|}
\hline \multirow[t]{2}{*}{ Newborn } & \multirow{2}{*}{$\begin{array}{c}\text { Gestatonal } \\
\text { age (weeks) }\end{array}$} & \multirow{2}{*}{$\begin{array}{c}\text { IRT1 } \\
\text { (ng/mL) }\end{array}$} & \multirow{2}{*}{$\begin{array}{c}\text { IRT2 } \\
\text { (ng/mL) }\end{array}$} & \multirow{2}{*}{$\begin{array}{l}\text { Sweat chlorine } \\
\qquad(\mathrm{mEq} / \mathrm{L})\end{array}$} & \multirow{2}{*}{$\begin{array}{c}\text { Onset of } \\
\text { symptoms } \\
\text { (day) }\end{array}$} & \multicolumn{3}{|c|}{ Clinical manifestations } & \multirow{2}{*}{$\begin{array}{c}\text { Age at 1st } \\
\text { evaluation } \\
\text { (day) }\end{array}$} \\
\hline & & & & & & $\begin{array}{c}\text { Gastro- } \\
\text { intestinal }\end{array}$ & Respiratory & Metabolic & \\
\hline 1 & 39 & 145.0 & 73.9 & 94.8 & 15 & & Yes & & 30 \\
\hline 2 & 37 & 83.4 & 89.2 & 83.0 & Birth & Yes & & & 53 \\
\hline 3 & 38 & 205.0 & 90.5 & 53.5 & Birth & Yes & & & 93 \\
\hline 4 & 36 & 140.0 & 93.7 & 112.6 & Birth & Yes & Yes & Yes & 48 \\
\hline 5 & 40 & 71.6 & 101.0 & 59.5 & Birth & Yes & Yes & & 35 \\
\hline 6 & 38 & 105.0 & 116.0 & 69.7 & Birth & & Yes & Yes & 41 \\
\hline 7 & 39 & 203.0 & 152.0 & 138.0 & Birth & Yes & & Yes & 35 \\
\hline 8 & 38 & 156.0 & 153.0 & 98.7 & Birth & Yes & & & 35 \\
\hline 9 & 39 & 194.0 & 165.0 & 70.9 & Birth & $\mathrm{MI}$ & & & 1 \\
\hline 10 & 33 & 154.0 & 172.0 & 126.3 & Birth & $\mathrm{MI}$ & & & 1 \\
\hline 11 & 37 & 251.0 & 191.0 & 197.0 & Birth & MI & & & 1 \\
\hline 12 & 38 & 303.0 & 226.0 & 131.1 & 15 & Yes & Yes & & 53 \\
\hline 13 & 38 & 485.0 & 232.0 & 88.8 & Birth & & Yes & & 31 \\
\hline 14 & 40 & 139.0 & 272.0 & 75.0 & Birth & Yes & & & 43 \\
\hline 15 & 35 & 317.0 & 295.0 & 170.0 & Birth & Yes & & Yes & 49 \\
\hline 16 & 35 & 187.0 & $\mathrm{NC}$ & 110.0 & Birth & & Yes & & 97 \\
\hline 17 & 39 & 83.4 & LC & 55.9 & 40 & Yes & Yes & Yes & 82 \\
\hline 18 & 38 & 166.0 & $\mathrm{NC}$ & 65.1 & Birth & Yes & Yes & & 51 \\
\hline 19 & 40 & 119.0 & $\mathrm{NC}$ & 53.7 & Birth & & & Yes & 90 \\
\hline 20 & 38 & 204.0 & 124.0 & 115.2 & Birth & Yes & & & 34 \\
\hline 21 & 38 & 143.0 & 120.0 & 52.1 & 30 & & & Yes & 34 \\
\hline 22 * & 39 & 298.0 & 189.0 & 59.7 & 23 & Yes & & & 25 \\
\hline 23 * & 26 & 77.0 & 74.2 & ND & Birth & $\mathrm{MI}$ & & & 33 \\
\hline $24 * \star$ & 40 & 39.0 & - & 88.3 & 60 & & Yes & Yes & 118 \\
\hline $25 * \star$ & 39 & 48.5 & - & 126.5 & 60 & & Yes & Yes & 264 \\
\hline $26 * \star$ & 37 & 92.9 & 54.8 & 63 & 60 & & Yes & & 475 \\
\hline
\end{tabular}

IRT: immunoreactive trypsinogen; LC: late collection; MI: meconium ileus; NC: not collected; ND: not done.

* Death;

** False negative.

The SCT was performed in 90 (88.2\%) of the babies with elevated IRT2 and $63(61.8 \%)$ had normal results (Figure 1). Fifteen children had a SCT $\geq 60 \mathrm{mEq} / \mathrm{L}$ : the diagnosis of CF was confirmed in all but one, with the latter being considered a false positive NBS test. The SCT of 12 babies was $\geq 30$ and $<60 \mathrm{mEq} / \mathrm{L}$ : CF was confirmed in four; seven of them were considered be false-positive NBS results and one NB died at three months of age.

Among the babies with IRT2 $\geq 70 \mathrm{ng} / \mathrm{mL}$, two were not subjected to the SCT due to loss of followup and ten died. One of the children who died had a diagnosis of meconium ileus at birth, and therefore a diagnosis of CF (Figure 1).

A total of 119 babies (6.2\%) were not subjected to the IRT2 (Figure 2): 23 died and ten were not located due to a change of address. Eighty-six NB were located and called for the SCT because they were older than one month. Among these children, the SCT was elevated in three, and CF was confirmed.

Thirty-two children had late IRT1 or IRT2 collections (Figure 3): ten died, one was lost to followup and 21 performed the SCT, which was positive in only one of them. 
Figure 1

Results of immunoreactive trypsinogen (IRT)/IRT screening strategy.

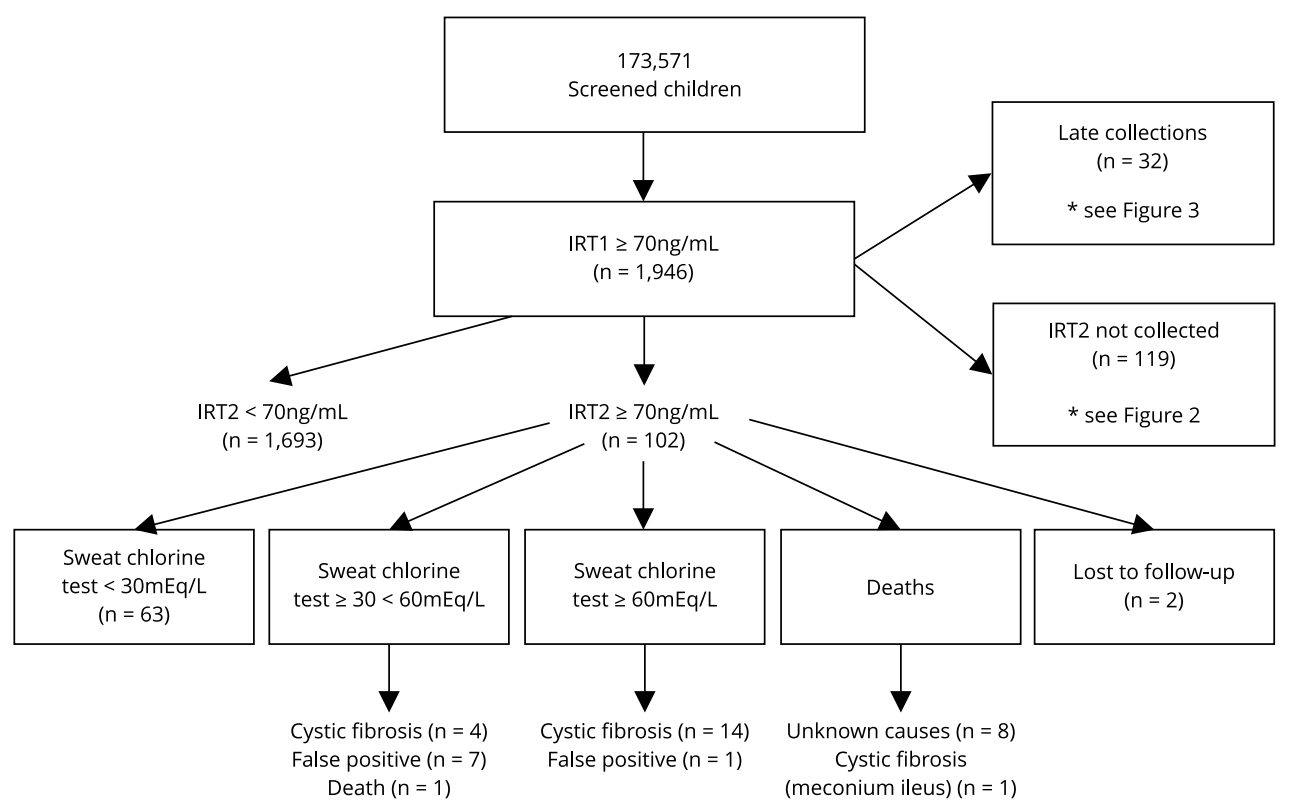

\section{Figure 2}

Results of cystic fibrosis screening strategy in children who did not harvest immunoreative trypsinogen (IRT2).

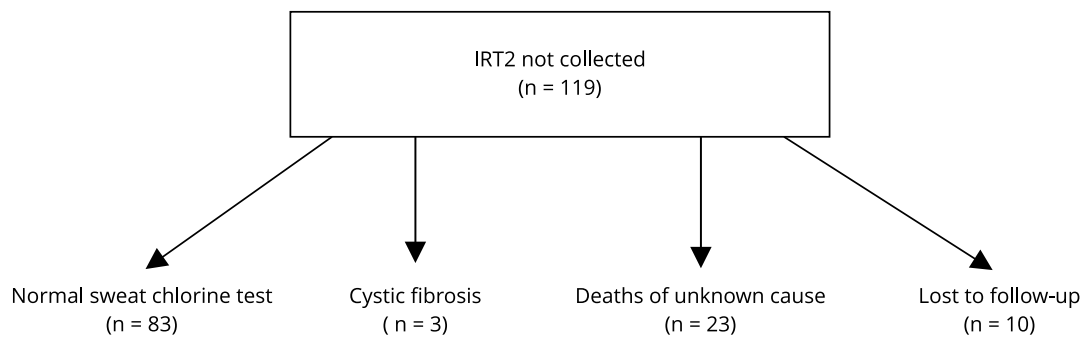

\section{Figure 3}

Results of cystic fibrosis screening strategy in children who had late collection of samples.

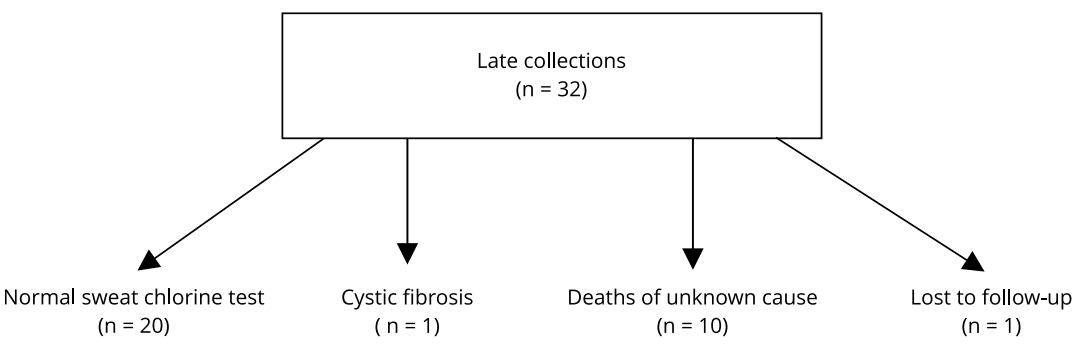


Forty-four deaths (2.3\%) occurred among the babies subjected to IRT1 collection during the study period $(n=1,946)$, one of them with meconium ileus and another with an elevated SCT who had actually started treatment with pancreatin but who died in her hometown and was not submitted to autopsy. Most of the babies who died had complex congenital cardiopathies, renal malformations, and genetic syndromes. Few of these babies' autopsy reports were obtained since most deaths occurred in their hometowns and autopsies are often not authorized by the parents in Brazil.

During the study period, three babies with a negative NBS test (false-negative result) were detected as having CF. The results of their SCTs were $63,88.3$ and $126.5 \mathrm{mEq} / \mathrm{L}$ and their age at diagnosis was 475, 264 and 118 days, respectively.

Considering all the cases detected $(\mathrm{n}=26)$ during the study period, one affected patient per 6,675 screened newborn was identified. Median age (IQR) at IRT2 collection was 26 (21.5-30.2) days and median age at the SCT was 44 days (34.5-59). Among the babies with an elevated IRT2 ( $=102)$, the result was false positive in 71 of them (69.6\%). The sensitivity of the NBS test using the IRT/IRT protocol for CF was $88.5 \%$, specificity was $98.9 \%$, the positive predictive value was $1.2 \%$, the negative predictive values was $99.9 \%$, and accuracy was $97.9 \%$.

The median age (IQR) at first evaluation was 42 (32-73) days for all babies detected by screening and 43 (35-81) days with the exclusion of four babies with meconium ileus (Table 1).

Almost all babies with CF already exhibited some clinical manifestations during the neonatal period, mainly gastrointestinal symptoms (17/26, 65.4\%) with four of them having meconium ileus, pulmonary symptoms $(12 / 26,46.1 \%)$ and metabolic symptoms $(9 / 26,34.6 \%)$. The complete patient characteristics for IRT, SCTs, and CFTR genotype are described in Tables 1 and 2.

Table 2

Molecular analysis data of newborns with cystic fibrosis detected at Hospital of the Ribeirão Preto Medical School, University of São Paulo, from February 2010 to January 2015.

\begin{tabular}{|c|c|c|}
\hline Newborn & Sanger sequencing & MLPA \\
\hline 1 & Positive for the F508del mutation in homozygosis in exon 11 in the CFTR gene & ND \\
\hline 2 & $\begin{array}{l}\text { Positive for the F508del and Leu997Phe mutations in heterozygosis in exons } 11 \text { and 19, } \\
\text { respectively in the CFTR gene }\end{array}$ & ND \\
\hline 3 & $\begin{array}{l}\text { Positive for the Met470Val mutation in homozygosis and F508del in heterozygosis, } \\
\text { both in exon } 11 \text { in the CFTR gene }\end{array}$ & $\begin{array}{l}\text { No deletions/No } \\
\text { duplications }\end{array}$ \\
\hline 4 & $\begin{array}{l}\text { Positive for the Gly85Glu and F508del mutations in heterozygosis in exons } 3 \text { and 11, } \\
\text { respectively, in the CFTR gene }\end{array}$ & F508del in heterozygosis \\
\hline 5 & Positive for the F508del mutation in homozygosis in exon 11 in the CFTR gene & F508del in homozygosis \\
\hline 6 & $\begin{array}{l}\text { Positive for the Pro205Ser mutation in exon } 6 \text { of the CFTR gene and for the pathogenic allele 5T/TG12 } \\
\text { In the IVS8 region in the CFTR gene }\end{array}$ & $\begin{array}{l}\text { No deletions/No } \\
\text { duplications }\end{array}$ \\
\hline 7 & $\begin{array}{l}\text { Positive for the Met470Val mutation in homozygosis in exon } 11 \text { and for Arg1162Stop in heterozygosis } \\
\qquad \text { in exon } 22 \text { in the CFTR gene }\end{array}$ & $\begin{array}{l}\text { No deletions/No } \\
\text { duplications }\end{array}$ \\
\hline 8 & Positive for the F508del mutation in homozygosis in exon 11 in the CFTR gene & F508del in homozygosis \\
\hline 9 & Positive for the F508del mutation in homozygosis in exon 11 in the CFTR gene & ND \\
\hline 10 & ND & ND \\
\hline 11 & ND & ND \\
\hline 12 & Positive for the F508del mutation in heterozygosis in exon 11 in the CFTR gene & F508del in heterozygosis \\
\hline 13 & $\begin{array}{l}\text { Positive for the Gly85Glu and F508del mutations in heterozygosis in exons } 3 \text { and 11, respectively, } \\
\text { in the CFTR gene }\end{array}$ & F508del in heterozygosis \\
\hline 14 & Positive for the Met470Val mutation in homozygosis in exon 11 in the CFTR gene & $\begin{array}{l}\text { No deletions/No } \\
\text { duplications }\end{array}$ \\
\hline 15 & Positive for the F508del mutation in homozygosis in exon 11 in the CFTR gene & ND \\
\hline 16 & Negative for mutations in the coding region of the CFTR gene & $\begin{array}{c}\text { Exon } 2 \text { deletion in } \\
\text { heterozygosis }\end{array}$ \\
\hline
\end{tabular}

(continues) 
Table 2 (continued)

\begin{tabular}{|c|c|c|}
\hline Newborn & Sanger sequencing & MLPA \\
\hline 17 & $\begin{array}{l}\text { Positive for the Ala349Pro mutations in exon } 8 \text { of the CFTR gene and for the pathogenic allele 5T/TG12 } \\
\qquad \text { In the IVS8 region in the CFTR gene }\end{array}$ & $\begin{array}{l}\text { No deletions/No } \\
\text { duplications }\end{array}$ \\
\hline 18 & $\begin{array}{l}\text { Positive for the mutations I148N in exon } 4 \text { and.Ile507del in exon 11, both in heterozygosis, in the CFTR } \\
\text { gene }\end{array}$ & ND \\
\hline 19 & $\begin{array}{l}\text { Positive for the Leu206Trp and F508del mutations in heterozygosis in exons } 6 \text { and 11, } \\
\text { respectively, in the CFTR gene }\end{array}$ & F508del in heterozygosis \\
\hline 20 & ND & ND \\
\hline 21 & $\begin{array}{l}\text { Positive for mutations Arg117His e Gly542Stop in heterozygosis in exons } 4 \text { and 12, } \\
\text { respectively, in the CFTR gene }\end{array}$ & ND \\
\hline $22 *$ & ND & ND \\
\hline $23 *$ & ND & ND \\
\hline $24 * *$ & ND & ND \\
\hline $25 * *$ & ND & ND \\
\hline $26 * *$ & ND & ND \\
\hline
\end{tabular}

CFTR: cystic fibrosis transmembrane regulatory; MLPA: Multiplex Ligation-dependent Probe Amplification assay; ND: not done.

* Death;

** False negative.

\section{Discussion}

During the study period, 176,562 births occurred according to the System of Information about Liveborns (SINASC) and 173,571 NB were screened at HCFMRP-USP, demonstrating excellent program coverage (98.3\%). IRT2 was collected in $93.4 \%$ of the babies and the frequency of IRT2 positivity was $5.3 \%$ among those with an elevated IRT1 and $0.6 \%$ considering the total number of babies screened. The screening test showed $88.5 \%$ sensitivity, but a high $98.9 \%$ specificity. The positive predictive value was $1.2 \%$, demonstrating that one of the negative factors about neonatal screening was that 1,899 families of supposedly healthy babies needed to live with the expectation of their children having CF, with a reduction to 102 families during the period between IRT2 and the SCT. The median age of affected babies at the time of the SCT was 42 days and the median age at first evaluation was 43 days, which was a positive factor both for an early release of babies without a diagnosis of CF and for an early intervention in babies with the disease.

The original IRT/IRT screening protocol was adopted in Brazil in view of the ethnic heterogeneity of its population 12,13. In the US, the IRT/IRT protocol is used in only $10 \%$ of NBs and its use is declining due to its low sensitivity, delayed diagnosis and high rate of false-positive results compared to the IRT/DNA protocol, which also promotes the identification of CF heterozygote carrier families for genetic counseling. However, the use of DNA analysis has several potential disadvantages like the recognition of babies with misidentified paternity ${ }^{17}$. A variation of the IRT/DNA method, called IRT/IRT/DNA, has been suggested, which requires the demonstration of persistent hypertrypsinogenemia for 1-2 weeks before DNA analysis 18. Although the time to diagnosis may be longer than in the IRT/DNA programs, IRT/IRT/DNA screening is more sensitive and detects fewer carriers 19.

Sanders et al. 20, in 2012, compared ages at diagnosis, genotyping, SCT, and first visit to a CF Center between US states that used serial IRT/IRT levels and states that used IRT/DNA analysis. In states using IRT/DNA, the babies were younger at the time of diagnosis (median 2.3 weeks versus 4.0 weeks, $\mathrm{p}<0.001)$ or genotyping $(0.7$ weeks versus 5.3 weeks, $\mathrm{p}<0.001)$, and the initial visit to the CF center occurred earlier (5.9 weeks versus 7.7 weeks, $\mathrm{p}=0.008$ ). At our center, the median age of affected babies at the first evaluation was 42 days and 43 days when excluding the babies with meconium ileus. Among the diagnosed cases, three did not harvest the IRT2 and one of them had the late collection (Figures 2 and 3). The diagnosis was made by the SCT performed at 51, 82, 90, and 97 days of life. 
The early age at the beginning of treatment at our center reflects the effort of the persons involved in the program so that, even though using the IRT/IRT protocol and despite the fact that a large number of babies did not perform the IRT2 or had a late collection. The SCT was performed in a timely manner for the babies to receive an early diagnosis and treatment comparable to those for the babies who were screened by the IRT/DNA protocol in the study by Sanders et al. 20.

Three babies had the CF diagnosis despite a negative NBS test. The diagnosis was made on a clinical basis and the interval until the beginning of treatment for these babies was longer compared to that of the other screened children, i.e., 118, 264, and 475 days of life under quite precarious health conditions. A delayed diagnosis of CF due to a previously negative NBS test indicates the need for further information including CF in the differential diagnosis of some diseases regardless of the NBS test 21. Fritz \& Farell 21 estimated 70 cases of false-negative results among 4,038,560 babies screened per year in the US using the IRT/DNA or IRT/IRT protocol. Thus, clinical and laboratory signs and symptoms suggestive of CF should not be ignored since a delayed diagnosis may have serious or even lethal consequences.

The frequency of CF in the present population was one in 6,675 screened newborns, a slightly higher value than that reported in a pilot study at this same center $(1: 8,403)$ involving a smaller number of babies and those reported for other Brazilian states (Paraná 1:9,520, Santa Catarina 1:8,776; Minas Gerais: 1:9,115) 22,23,24.

Most of the babies with CF already showed some clinical manifestations at diagnosis (Table 1), although none of them had been diagnosed previously. The lack of a diagnosis even in the presence of clinical manifestations underscores the importance of the test for the population involved since the mean age at diagnosis is higher without NBS.

Improved nutrition was the primary benefit of CF-NBS identified in the randomized controlled trial conducted by Farrell et al. 25 and continues to be the most significant outcome of an early diagnosis 26 . Tluczek et al. 27 reported no difference in pulmonary function or quality of life outcomes between screening and control patients when controlling for pancreatic function and Pseudomonas aeruginosa infection. However, other studies indicate a protective benefit of CF-NBS for nutritional status and pulmonary function as well as reduced complications 28,29 .

Previously considered lethal in infancy and childhood, CF has now permitted a median survival of 50 years of age in affected patients, mainly thanks to an early diagnosis through NBS, recognition of mild forms, and an aggressive therapeutic attitude.

Most of the affected babies studied here were subjected to a genetic study and the mutation most frequently detected was that most commonly encountered in all populations, i.e., F508del, which is detected in approximately $70 \%$ of CF cases around the world 30 .

Therefore, due to the heterogeneity of clinical features already described in CF, it becomes important to include the screening for mutations in the CFTR gene in the CF-NBS. Thus, the majority of suspected cases of CF would be detected early, favoring early treatment and management of the disease.

In conclusion, the incidence of CF among the screened babies was 1:6,675. The median age at IRT1 collection of the babies with altered results was five days. Because of an active search, most babies (93.4\%) came for IRT2 collection at a median age of 26 days, a time that will need to be reduced in order to obtain an earlier diagnosis. The median age at the first evaluation for babies with confirmed diagnosis, excluding those with meconium ileus, was 43 days. Neonatal screening permitted the beginning of treatment at an earlier age, although most babies already showed some clinical manifestations of the disease. Considering the false negative results of CF-NBS and the early onset of clinical manifestations of the disease in this study, pediatricians should be aware of the diagnosis of $\mathrm{CF}$ even in children with negative test. 


\section{Contributors}

All authors contributed in the conception and design, acquisition of data, analysis and drafting of the manuscript.

\section{Additional informations}

ORCID: Léa Maria Zanini Maciel (0000-00031447-0794); Patrícia Künzle Ribeiro Magalhães (0000-0003-2564-7903); Ieda Regina Lopes Del Ciampo (0000-0002-7862-0221); Maria Luísa Barato de Sousa (0000-0002-0787-9412); Maria Inez Machado Fernandes (0000-0002-0737-5062); Regina Sawamura (0000-0001-9688-9382); Roberta Rodrigues Bittar (0000-0002-9660-6677); Greice Andreotti de Molfetta (0000-0003-0946-5704); Wilson Araújo da Silva Júnior (0000-0001-93642886).

\section{References}

1. Comeau AM, Parad RB, Dorkin HL, Dovey M, Gerstle R, Haver K, et al. Population-based newborn screening for genetic disorders when multiple mutation DNA testing is incorporated: a cystic fibrosis newborn screening model demonstrating increased sensitivity but more carrier detections. Pediatrics 2004; 113:157381.

2. Sontag MK, Hammond KB, Zielenski J, Wagener JS, Accurso FJ. Two-tiered immunoreactive trypsinogen-based newborn screening for cystic fibrosis in Colorado: screening efficacy and diagnostic outcomes. J Pediatr 2005; 147(3 Suppl):S83-8.

3. Parad RB, Comeau AM. Newborn screening for cystic fibrosis. Pediatr Ann 2003; 32:52835.

4. Raskin S, Pereira-Ferrari L, Caldeira Reis F, Abreu F, Marostica P, Rozov T, et al. Incidence of cystic fibrosis in five different states of Brazil as determined by screening of p.F508del, mutation at the CFTR gene in newborns and patients. J Cyst Fibros 2008; 7:15-22.

5. Rodrigues R, Magalhaes PKR, Fernandes MIM, Gabetta CS, Ribeiro AF, Pedro KP, et al. Neonatal screening for cystic fibrosis in São Paulo State, Brazil: a pilot study. Braz J Med Biol Res 2009; 42:973-8.

6. Tsui L, Rommens J, Kerem B, Rozmahel R, Zielenski J, Kennedy D, et al. Molecular genetics of cystic fibrosis. Adv Exp Med Biol 1991; 290:9-17.

7. Cystic Fibrosis Mutation Database. http:// www.genet.sickkids.on.ca/ (accessed on 28/ Nov/2017).

8. Crossley JR, Elliott RB SP. Dried-blood spot screening for cystic fibrosis in the newborn. Lancet 1979; 1:472-4.

9. Castellani C, Massie J, Sontag M, Southern KW Newborn screening for cystic fibrosis. Lancet Respir Med 2016; 4:653-61.

10. Wilcken B. Newborn screening for cystic fibrosis: techniques and strategies. J Inherit Metab Dis 2007; 30:537-43.

11. Rock MJ, Mischler EH, Farrell PM, Wei LJ, Bruns WT, Hassemer DJ, et al. Newborn screening for cystic fibrosis is complicated by age-related decline in immunoreactive trypsinogen levels. Pediatrics 1990; 85:1001-7.

12. Gregg RG, Simantel A, Farrell PM, Koscik R, Kosorok MR, Laxova A, et al. Newborn screening for cystic fibrosis in Wisconsin: comparison of biochemical and molecular methods. Pediatrics 1997; 99:819-24.

13. Narzi L, Lucarelli M, Lelli A, Grandoni F, Cicero SL, Ferraro A. Comparison of two different protocols of neonatal screening for cystic fibrosis. Clin Genet 2002; 62:245-9.

14. Gibson L, Cooke R. A test for concentration of electrolytes in sweat in cystic fibrosis of the pancreas utilizing pilocarpine by iontophoresis. Pediatrics 1959; 23:545-9. 
15. Scharles O, Scharles S. A simple and accurate method for the determination of chloride in biological fluids. J Biol Chem 1941; 140:87984.

16. Grosse SD, Boyle CA, Botkin JR, Comeau AM, Kharrazi MRM. Newborn screening for cystic fibrosis: evaluation of benefits and risks and recommendations for state newborn screening programs. MMWR Recomm Rep 2004; 53(RR-13):1-36.

17. Wilfond BS, Fost N. The cystic fibrosis gene: medical and social implications for heterozygote detection. JAMA 1990; 263:2777-83.

18. Padoan R, Genoni S, Moretti E, Seia M, Giunta A, Corbetta C. Genetic and clinical features of false-negative infants in a neonatal screening programme for cystic brosis. Acta Paediatr 2002; 91:82-7.

19. Sontag MK, Lee R, Wright DB, Freedenberg D, Sagel SD. Improving the Sensitivity and positive predictive value in a cystic fibrosis newborn screening program using a repeat immunoreactive trypsinogen and genetic analysis. $\mathrm{J}$ Pediatr 2016; 175:150-8.e1.

20. Sanders DB, Lai HJ, Rock MJ, Farrell PM. Comparing age of cystic fibrosis diagnosis and treatment initiation after newborn screening with two common strategies. J Cyst Fibros 2012; 11:150-3.

21. Fritz A, Farrell P. Estimating the annual number of false negative cystic fibrosis newborn screening tests. Pediatr Pulmonol 2012; 47:207-8.

22. Santos G, Domingos M, Wittig E, Riedi C, Rosário N. Neonatal cystic fibrosis screening program in the state of Paraná: evaluation 30 months after implementation. J Pediatr (Rio J.) 2005; 81:240-4.
23. Honorio L, Ludwig Neto N, Barbosa E, Perin N, Gastaldi L, Ferreira J. Avaliação da triagem neonatal para fibrose cística no Estado de Santa Catarina. J Bras Pneumol 2006; 32(1 Suppl):1-16.

24. Reis F, Melo S, Vergara A. Programa de triagem neonatal para fibrose cística de Minas Gerais. J Bras Pneumol 2006; 32(1 Suppl):1-16.

25. Farrell PM, Kosorok MR, Laxova A, Shen G, Koscik R, Bruns WT, et al. Nutritional benefits of neonatal screening for cystic fibrosis. $\mathrm{N}$ Engl J Med 1997; 337:963-9.

26. Salvatore D, Buzzetti R, Baldo E, Pia M, Lucidi $\mathrm{V}$, Manunza D, et al. An overview of international literature from cystic fibrosis registries 2 . Neonatal screening and nutrition/growth. J Cyst Fibros 2010; 9:75-83.

27. Tluczek A, Becker T, Laxova A, Grieve A, Gilles CNR, Rock MJ, et al. Relationships among health-related quality of life, pulmonary health, and newborn screening for cystic fibrosis. Chest 2011; 140:170-7.

28. Rosenfeld M, Emerson J, Mcnamara S, Joubran K, Retsch-bogart G, Graff GR, et al. Baseline characteristics and factors associated with nutritional and pulmonary status at enrollment in the cystic fibrosis EPIC observational cohort. Pediatr Pulmonol 2010; 45:934-44.

29. Accurso FJ, Sontag MK, Wagener JS. Complications associated with symptomatic diagnosis in infants with cystic fibrosis. J Pediatr 2005; 147(3 Suppl):S37-41.

30. Bombieri C, Castellani C. Genotypes and phenotypes in cystic fibrosis and cystic fibrosis transmembrane regulator - related disorders. Semin Respir Crit Care Med 2015; 36:180-93. 


\section{Resumo}

O Hospital das Clínicas da Faculdade de Medicina de Ribeirão Preto, Universidade de São Paulo é um dos três centros de triagem da fibrose cística (FC) no estado de São Paulo, tendo incluído esse teste desde 6 de fevereiro de 2010, a partir de uma liminar judicial. O estudo avalia os primeiros cinco anos desse programa de triagem neonatal da FC. $O$ Brasil adota o protocolo de triagem original, com o tripsinogênio imunorreativo (IRT)/IRT. Foram triados um total de 173.571 recém-nascidos, dos quais $1.922(1,1 \%)$ mostraram IRT $\geq 70 \mathrm{ng} /$ $m L$. Destes, 1.795 (93,4\%) tiveram amostras coletadas para IRT2, com resultados elevados (IRT2 $\geq$ $70 \mathrm{ng} / \mathrm{mL}$ ) em 102 deles (5,2\%). Identificamos um total de 26 casos de FC durante esse período, inclusive 3 casos de FC que não foram detectados com a triagem neonatal. A incidência da FC foi de $1 \mathrm{ca-}$ so em cada 6.675 recém-nascidos triados. A idade mediana na avaliação inicial foi 42 dias, comparável à idade de recém-nascidos triados com o protocolo IRT/DNA. Quase todos os lactentes com FC já exibiam algumas manifestações da doença durante o período neonatal. A mutação mais comum nos casos de FC foi a F508del. Os resultados em nosso centro indicam que a idade precoce no início do tratamento foi devido aos esforços do programa na implementação de uma busca ativa eficaz. Considerando os resultados falsos-negativos no programa de triagem neonatal para FC e o inicio precoce das manifestações clínicas da doença neste estudo, os pediatras devem estar cientes da possibilidade de diagnóstico de FC, mesmo em crianças com teste negativo.

Fibrose Cística; Triagem Neonatal; Tripsinogênio

\section{Resumen}

El Hospital das Clínicas de la Facultad de Medicina de Ribeirão Preto, São Paulo Universidad es uno de los tres centros de cribado de fibrosis cística (FC) en el estado de São Paulo, incluyendo este test desde el 6 de febrero de 2010, debido a una medida cautelar judicial. El estudio evalúa los primeros cinco años de este programa de cribado neonatal de FC. Brasil adopta el protocolo de cribado original, con el tripsinógeno inmunorreactivo (TIR)/ IRT. Se cribaron un total de 173.571 recién nacidos, de los cuales $1.922(1,1 \%)$ mostraron IRT $\geq$ $70 n g / m L$. De estos, se obtuvieron 1.795 (93,4\%) muestras recogidas para IRT2, con resultados elevados (IRT2 $\geq 70 \mathrm{ng} / \mathrm{mL}$ ) en 102 de ellos $(5,2 \%)$. Identificamos un total de 26 casos de FC durante ese período, inclusive 3 casos de FC que no fueron detectados con el cribado neonatal. La incidencia de la FC fue de 1 caso por cada 6.675 reciénnacidos cribados. La edad media en la evaluación inicial fue 42 dias, comparable a la edad de recién nacidos cribados con el protocolo IRT/DNA. Casi todos los lactantes con FC ya manifestaban algunos sintomas de la enfermedad durante el período neonatal. La mutación más común en los casos de FC era el F508del. Los resultados en nuestro centro indican que la edad precoz en el inicio del tratamiento se debía a los esfuerzos del programa en la implementación de una búsqueda activa eficaz. Considerando los resultados falsos-negativos en el programa de cribado neonatal para FC, y el inicio precoz de las manifestaciones clínicas de la enfermedad en este estudio, los pediatras deben ser conscientes de la posibilidad de diagnóstico de FC, incluso en niños con test negativo.

Fibrosis Quística; Tamizaje Neonatal;

Tripsinógeno
Submitted on 18/Mar/2019

Final version resubmitted on 25/Jun/2019

Approved on 20/Mar/2020 